Notes and Comments

\title{
First report of Raillietiella mottae (Pentastomida: Raillietiellidae) infecting Rhinella diptycha (Anura, Bufonidae) in the Brazilian Northeast
}

\author{
Primeiro registro de Raillietiella mottae (Pentastomida: Raillietiellidae) infectando \\ Rhinella diptycha (Anura, Bufonidae) no Nordeste, Brasil
}

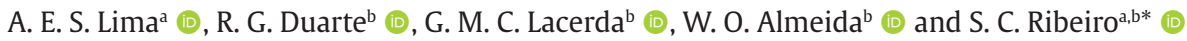 \\ aUniversidade Federal do Cariri - UFCA, Instituto de Formação de Educadores - IFE, Laboratório de Biologia e Ecologia de Animais Silvestres - \\ LABEAS, Brejo Santo, CE, Brasil \\ bUniversidade Regional do Cariri - URCA, Departamento de Química Biológica, Programa de Pós-graduação em Diversidade Biológica e \\ Recursos Naturais, Crato, CE, Brasil
}

Pentastomids are hematophagous parasites whose adult forms live in the respiratory tract of their hosts. There are approximately 144 valid species of Pentastomida distributed in four orders (Christoffersen and Assis, 2013). Some pentastomid species are host-generalist (Almeida et al., 2009) while others are host-specific (Riley, 1986). Parasites of the genus Raillietiella (order Raillietiellida) are commonly found in reptiles, but occur also in amphibians (Christoffersen and Assis, 2013).

Amphibians can harbor a great variety of parasites, acting as definitive, intermediate, and paratenic hosts, as in the case of Rhinella diptycha (Cope, 1862) (Bufonidae), which has been reported as host to various species of helminths (Amorim et al., 2019). This large-bodied anuran is widely distributed in the Brazilian Northeast, especially in areas of Caatinga, and is known to occupy a variety of environments, including urban areas, alongside roads, and in landfills (Borges-Nojosa and Santos, 2005). The present note reports the occurrence of the pentastomid $R$. mottae (Almeida, Lopes and Freire, 2008) in the anuran R. diptycha in the State of Ceará, in the Brazilian Northeast.

Sampling of $R$. diptycha specimens was carried out between January and May 2018, in 10 municipalities in the south of the state of Ceará, Northeastern, Brazil. Two sampling points were determined in each of these municipalities, with one of them being always an area with a high degree of anthropogenic influence (landfill) and the other an area with a relatively low degree of anthropogenic influence (i.e., forest remnants).

The anurans were captured manually, placed in polyethylene bags, and transported to the laboratory where they were weighed with a digital scale ( $0.01 \mathrm{~g}$ precision) and measured with a digital caliper. The specimens were killed with a lethal injection of $2 \%$ lidocaine hydrochloride (CFMV, 2013) and then dissected for examination of all internal organs for parasites, using a stereomicroscope.
The sex of the animals was determined by analysis of the gonads. The pentastomids found were analyzed and counted, then preserved in $70 \%$ ethanol. Specimens were mounted on temporary slides with Hoyer's solution and identified to species based on their body size, male copulatory spicules, and dimensions of hooks (Ali et al., 1985). Maturity of pentastomids was determined by the presence of eggs inside the abdomen in females, and copulatory spicules in males. The parasitological prevalence indices were analyzed as indicated by Bush et al. (1997).

A license for collecting the toads was obtained from the Chico Mendes Institute of Biodiversity Conservation 'Instituto Chico Mendes de Conservação da Biodiversidade' (ICMBio/SISBio, license No: 61743-1) and the Ethics Committee on Animal Use from Universidade Federal do Cariri - UFCA (approved protocol number: 006/2018), accredited by the Comissão Nacional de Ética em Pesquisa - CONEP. Every step of the research followed the guidelines of the Society for the Study of Amphibians and Reptiles, American Society of Ichthyologists and Herpetologists (ASIH), and the Conselho Brasileiro de Biologia (CBO). Voucher specimens of frogs and parasites are deposited in the Herpetological Collection of Regional University of Cariri 'Universidade Regional do Cariri (URCA-H 15279-15288)', and the Herpetological Collection of the 'Universidade Federal do Cariri (CHERP-P-UFCA 30)'.

A total of 210 specimens of $R$. diptycha were collected, being 96 adult males (mean SVL=144.6 $\pm 29.9 \mathrm{~mm}$ ), 92 adult females (mean SVL=161.2 $\pm 20.8 \mathrm{~mm}$ ), and 22 juveniles (mean $S V L=83.3 \pm 15.3 \mathrm{~mm}$ ). Among all frogs dissected, only one individual (adult female, SVL=155.4, body mass $=621 \mathrm{~g}$ ), from a landfill in the municipality of Porteiras ( $7^{\circ} 31^{\prime} 59.67^{\prime \prime} \mathrm{S}$; 39²'25.57" W), was infected by six adult specimens of the pentastomid. Raillietiella mottae $(0.48 \%$ prevalence) found in lungs.

*e-mail: samuel.ribeiro@ufca.edu.br

Received: January 19, 2021 - Accepted: October 25, 2021 
Motta and Gomes (1968) presented the first record of adult pentastomids infecting adult amphibians in South America. Those authors identified the parasite as Raillietiella freitasi (Motta and Gomes, 1968) (=Cephalobaena freitasi) infecting Mabuya punctata [= Trachylepis atlantica (Schmidt, 1945)], Tropidurus torquatus (Wied-Neuwied, 1820), and Bufo paracnemis [=Rhinella diptycha (Cope, 1862)]. The latter record was contested by Rego (1983) after reviewing the fixed material. Rego (1983) pointed out that, despite the existence of studies reporting pentastomid larvae in amphibians, there was no mention of adult and stated the possibility of erroneous identification of the parasite. Indeed, the majority of studies report cases of parasitism by pentastomid larvae in adult amphibians (Ali et al., 1982). However, the record of Motta and Gomes (1968) could refer to an uncommon case, and therefore should be considered as valid.

Our new records indicate that the information presented by Motta and Gomes (1968) might have been discredited due to a lack of knowledge about the potential of these parasites to establish themselves in adult anurans. Additionally, the presence of $R$. mottae in $R$. diptycha represents a new host record, as well as the second record of an adult pentastomid infecting an adult amphibian in South America, thus adding to the knowledge on hostparasite relationships of pentastomids.

The low prevalence $(0.48 \%)$ indicates that parasitism by $R$. mottae in $R$. diptycha is uncommon and possibly occasional or accidental, as suggested for some lizards (Ribeiro et al., 2012; Silva et al., 2019), which are also uncommon hosts of this pentastomid.

\section{Acknowledgements}

We are grateful to the Conselho Nacional de Desenvolvimento Científico e Tecnológico - CNPq, Coordenação de Aperfeiçoamento de Pessoal de Nível Superior - CAPES, and Pró- Reitoria de Pesquisa e Inovação Universidade Federal do Cariri for the research grant awarded for this study. We thank the Fundação Cearense de Apoio ao Desenvolvimento Científico e Tecnológico (BPI - FUNCAP: BP3-0139-00323.01.00/18; BP4-00172- 00223.01.01/20).

\section{References}

ALI, J.H., RILEY, J. and SELF, J.T., 1982. Amphibians as definititive hosts for pentastomids: raillietiella bufonis n.sp. from Bufo lemur in Puerto Rico and a reassessment of Raillietiella indica Gedoelst, 1921. Systematic Parasitology, vol. 4, no. 3, pp. 279284. http://dx.doi.org/10.1007/BF00009630.

ALI, J.H., RILEY, J. and SELF, J.T., 1985. A review of the taxonomy and systematics of the pentastomids genus Raillietiella Sambon, 1910 with a description of a new species. Systematic Parasitology, vol. 7, no. 2, pp. 111-123. http://dx.doi.org/10.1007/BF00009814.

ALMEIDA, W.O., SANTANA, G.G., VIEIRA, W.L.S., WANDERLEY, I.C. and RIBEIRO, S.C., 2009. Rates of pulmonary infection by pentastomids in lizards species from a restinga habitat in northeastern Brazil. Brazilian Journal of Biology = Revista Brasileira de Biologia, vol. 69, no. 1, pp. 197-200. http://dx.doi. org/10.1590/S1519-69842009000100026. PMid:19347165.

AMORIM, D.M., OLIVEIRA, R.H., DYNA, C.S., SOUSA, D.M., SANTOS, E.P., LIMA, L.S., PINTO, L.C. and AVILA, R.W., 2019. Nematodes parasites of Rhinella jimi (Stevaux, 2002) (Anura: Bufonidae) in areas of caatinga, northeastern Brazil. Neotropical Helminthology, vol. 13, pp. 265-271. http://dx.doi.org/10.24039/rnh2019132647.

BORGES-NOJOSA, D. and SANTOS, E.M., 2005. Herpetofauna da área de Betânia e Floresta, Pernambuco. In: F.S. ARAÚJO, M.J.N. RODAL \& M.R.V. BARBOSA, eds. Análise das variações da biodiversidade do Bioma Caatinga - Suporte a estratégias regionais de conservação. Brasília: Ministério do Meio Ambiente, Secretaria de Biodiversidade e Florestas, pp. 276-289.

BUSH, A.O., LAFFERTY, K.D., LOTZ, J.M. and SHOSTAK, A.W., 1997. Parasitology meets ecology on its own terms: margolis et al. revisited. The Journal of Parasitology, vol. 83, no. 4, pp. 575-583. http://dx.doi.org/10.2307/3284227. PMid:9267395.

CHRISTOFFERSEN, M.L. and ASSIS, J.E., 2013. A systematic monograph of the Recent Pentastomida, with a compilation of their hosts. Zoölogische Mededeelingen, vol. 87, no. 1, pp. 1-206.

CONSELHO FEDERAL DE MEDICINA VETERINÁRIA - CFMV, 2013. Métodos de eutanásia. In: COMISSÃO DE ÉTICA, BIOÉTICA E BEM-ESTAR ANIMAL - CFMV. Guia brasileiro de boas práticas de eutanásia em animais. Brasília: CFMV, pp. 28-29.

MOTTA, C.S., and GOMES, D.C., 1968. Sobre um novo gênero e uma nova espécie de Cephalobaenidae (Linguatulida, Cephalobaeniformia). Atas da Sociedade de Biologia do Rio de Janeiro, vol. 12, no. 1, pp. 7-9.

RÊGO, A.A., 1983. Pentastomídeos de répteis do Brasil: revisão dos Cephalobaenidae. Memorias do Instituto Oswaldo Cruz, vol. 78, no. 4, pp. 399-411. http://dx.doi.org/10.1590/S007402761983000400003.

RIBEIRO, S.C., FERREIRA, F.S., BRITO, S.V., TELES, D.A., ÁVILA, R.W., ALMEIDA, W.O., ANJOS, L.A. and GUARNIERI, M.C., 2012. Pulmonary infection in two sympatric lizards, Mabuya arajara (Scincidae) and Anolis brasiliensis (Polychrotidae) from a cloud forest in Chapada do Araripe, Ceará, Northeastern Brazil. Brazilian Journal of Biology = Revista Brasileira de Biologia, vol. 72, no. 4, pp. 929-933. http://dx.doi.org/10.1590/S151969842012000500021. PMid:23295524.

RILEY, J., 1986. The biology of pentastomids. Advances in Parasitology, vol. 25, pp. 45-128. http://dx.doi.org/10.1016/ S0065-308X(08)60342-5. PMid:3535437.

SILVA, E.G., SANTOS, M.E.P., BRITO, S.V., ALMEIDA, W.O. and RIBEIRO, S.C., 2019. Raillietiella mottae (Pentastomida: Raillietiellidae) infecting Ameiva ameiva (Squamata: Teiidae) in Araripe Plateau, Northeast Brazil. Brazilian Journal of Biology $=$ Revista Brasileira de Biologia, vol. 79, no. 1, pp. 100-103. http://dx.doi. org/10.1590/1519-6984.178609. PMid:29694565. 